\title{
The changing landscape for health research in Africa: The focus of the Southern African Centre for Infectious Diseases and Surveillance
}

\author{
Authors: \\ Mark M. Rweyemamu \\ Esron D. Karimuribo ${ }^{1}$ \\ Leonard E.G. Mboera²

\section{Affiliations:} \\ ${ }^{1}$ Southern African Centre \\ for Infectious Disease \\ Surveillance, Sokoine \\ University of Agriculture, \\ Tanzania \\ ${ }^{2}$ National Institute for \\ Medical Research, Dar es \\ Salaam, Tanzania \\ Correspondence to: \\ Mark Rweyemamu \\ Email: \\ mark.rweyemamu@ \\ btinternet.com \\ Postal address: \\ PO Box 3019, Chuo Kikuu, \\ Morogoro, Tanzania \\ How to cite this article: \\ Rweyemamu, M.M., \\ Karimuribo, E.D. \& Mboera, \\ L.E.G., 2014, 'The changing \\ landscape for health research \\ in Africa: The focus of the \\ Southern African Centre \\ for Infectious Diseases and \\ Surveillance', Onderstepoort \\ Journal of Veterinary \\ Research 81(2), Art. \#799, 2 \\ pages. http://doi:10.4102/ \\ ojvr.v81i2.799 \\ Note: \\ Proceedings of the 2 nd \\ One Health Conference in \\ Africa. Jointly organised \\ by the Southern African \\ Centre for Infectious Disease \\ Surveillance and the Tanzania \\ National Institute for Medical \\ Research, held at the Snow \\ Crest Hotel in Arusha, \\ Tanzania from 16th to 19th \\ April 2013: http://www. \\ sacids.org/kms/frontend/ \\ index.php?m=119.

In April 2013, the Southern African Centre for Infectious Diseases and Surveillance (SACIDS) (see http:/ / www.sacids.org) joined forces with the Tanzania National Institute for Medical Research to convene the Second One Health Conference in Africa, held in Arusha, Tanzania, with the overarching theme of 'The changing landscape for health research in Africa'.

Whilst this reflection covered both communicable and con-communicable diseases, the greater emphasis was on infectious or communicable diseases. This reflects the impact of these diseases on human health, well-being and economic development in Africa (Mboera et al. 2014; Rweyemamu, Otim-Nape \& Serwadda 2006; Rweyemamu et al. 2012). The heavy burden of infectious diseases of humans and animals in Africa falls into two categories, namely, (1) exposure to internally or externally generated emerging or re-emerging diseases and (2) the continuing occurrence of major epidemic diseases in an endemic state in Africa.

It has been reported that about $60 \%$ of all infectious pathogens in humans originate from animals, although many of these have completely adapted to their new host and no longer require a nonhuman animal host for persistence. It is also known that between $60 \%$ and $75 \%$ of new or emerging infectious diseases of humans in the last half century have originated from animals, of which perhaps $71 \%$ of these were of wildlife origin. The drivers of many emerging diseases are mostly related to human behaviour and actions, socio-economic (e.g. globalisation of travel and trade), environmental and ecological factors (Jones et al. 2008; Lightfoot, Rweyemamu \& Heymann 2013; Rweyemamu et al. 2006; Taylor et al. 2001).

The continuing endemic settings of major infectious diseases in Africa constitute a high risk for health and livelihoods and future marginalisation of Africa through trade restrictions and sociopolitical impacts (Rweyemamu et al. 2012; Waage et al. 2010). In Africa, $72 \%$ of the disease burden is attributable to poverty, interactions between socio-economic opportunities and the health of animals, people and ecosystems, compared to $27 \%$ in the rest of the world. Another important aspect of health in Africa is climate change and variability, which is reported to have affected Africa more heavily than most other parts of the world. Generally, vulnerability of individuals and communities to infectious diseases is influenced by multiple factors (environmental, economic and socio-ecological) in addition to host and causative agent factors (Food and Agriculture Organization of the United Nations [FAO] 2013; McMichael \& Woodruff 2004; Ndiyoi et al. 2006; World Health Organization 2011).

Accordingly, there is an increasing consensus that because of their holistic nature, One Health $(\mathrm{OH})$ and/or EcoHealth approaches are particularly appropriate for the risk management of infectious diseases in Africa (Charron 2012; Mboera et al. 2014; Rweyemamu et al. 2013; Zingstagg et al. 2011). Furthermore, the World Bank and several independent authors have shown that these approaches are cost-effective (Grace 2014; Rushton 2012; World Bank 2012).

In pursuance of the same goal in Africa, SACIDS has developed a broad-based, OH-driven approach to infectious diseases in sub-Saharan Africa through its vision of:

A sub-Saharan African society protected from devastating infectious diseases affecting the health of humans, animals, i.e. both terrestrial and aquatic, and ecosystems, thereby promoting livelihoods, socioeconomic development including market access and the environment. (SACIDS n.d.)

The modus operandi of SACIDS is that of a virtual centre which links African academic and research institutions that deal with infectious diseases of humans and animals in smart partnership with centres of research excellence in industrialised countries and international research centres. SACIDS has adopted the community of practice (CoP) approach for 
both its research capacity development programme and its collaboratively themed research programme (Rweyemamu et al. 2012, 2013). Following an internal review and development of a new business plan to 2020, the programme of SACIDS now revolves around the following six themes or CoPs, (1) emerging and vectorborne diseases, (2) bacterial zoonoses including food-borne diseases and anti-microbial resistance, (3) viral diseases of food security importance, (4) cross-cutting OH sciences, (5) $\mathrm{OH}$ training (short-courses, annual $\mathrm{OH}$ summer schools and $\mathrm{OH}$-based MSc courses) and (6) research management and an $\mathrm{OH}$ forum, including conferences.

Whilst the first three themes are disease-category based, themes four and five help SACIDS to develop a broadbased approach, which includes socio-economics, socioanthropology, environment, ecosystems, EcoHealth, OHbased and information communication and technology driven approaches to disease surveillance, health systems and policy, poverty focus and an examination of such issues as the interaction between agriculture and health (Karimuribo et al. 2012; Kayunze et al. 2014; Mboera et al. 2014; Mwabukusi et al. 2014; Rweyemamu et al. 2013). That is the SACIDS approach to the changing landscape for health research in Africa, as it strives to evolve into a regional One Health forum and research platform in Africa (theme six).

\section{Acknowledgements}

We acknowledge, with thanks, the funding agencies for SACIDS, especially the Wellcome Trust through Grant WT087546MA, the Rockefeller Foundation through grants 2008-DSN310, 2009-DSN305 and 2011-DSN307, the Google Foundation through grant GF-02-2009 and the International Development Research Centre through grant 107030-001. We also acknowledge the specific action financial support received from FAO and the Foresight Programme of the UK Government.

\section{Competing interests}

The authors declare that they have no financial or personal relationships which may have inappropriately influenced them in writing this article.

\section{Authors' contributions}

M.M.R. (Sokoine University of Agriculture) produced the first draft of the manuscript, building on shared vision by the three authors, who have all been involved in the organisation of the One Health conference. M.M.R. also undertook the primary literature review. E.D.K. (Sokoine University of Agriculture) and L.E.G.M. (National Institute for Medical Research) reviewed the text and improved it with additional references and all the three authors agreed upon the final version.

\section{References}

Charron, D.F., 2012, Ecohealth research in practice: Innovative applications of an ecosystem approach to health, Springer, Ottawa, viewed 03 April 2014, from http://www.idrc.ca/EN/Resources/Publications/Pages/IDRCBookDetails. aspx?PublicationID=1051

Food and Agriculture Organization of the United Nations, 2013, World livestock 2013 - Changing disease landscapes, FAO, Rome.

Grace, D., 2014, 'The business case for One Health', Onderstepoort Journal of Veterinary Research 81(2), Art. \#725, 6 pages. http://dx.doi.org/10.4102/ojvr. v81i2.725

Jones K.E., Patel, N., Levy, M.A., Storeygard, A., Balk, D., Gittleman, J.L. et al.,2008, 'Global trends in emerging infectious diseases', Nature 451, 990-993. http:// dx.doi.org/10.1038/nature06536

Karimuribo, E.D., Sayalel, K., Beda, E., Short, N., Wambura, P., Mboera, L.G. et al., 2012 , 'Towards one health disease surveillance: The Southern African Centre for Infectious Disease Surveillance approach', Onderstepoort Journal of Veterinary
Intion Infectious Disease Surveillance approach', Onderstepoort Journal of Veterinar
Research 79(2), Art. \#454, 7 pages. http://dx.doi.org/10.4102/ojvr.v79i2.454

Kayunze, K.A., Kiwara, A., Lyamuya, E., Kambarage, D.M., Rushton, J., Coker, R. et al., 2014, 'Practice of One Health approaches: Bridges and barriers in Tanzania', Onderstepoort Journal of Veterinary Research 81(2) Art. \#733, 8 pages. http:// Onderstepoort Journal of Veterinary
dx.doi.org/10.4102/ojvr.v81i2.733

Lightfoot, N., Rweyemamu, M. \& Heymann, D.L., 2013. 'Preparing for the next pandemic. Greater cross sector collaboration between health, veterinary, wildlife and environmental experts is needed', British Medical Journal 346, f364. http:// dx.doi.org/10.1136/bmj.f364

Mboera, L.E.G., Mfinanga, S.G., Karimuribo, E.D., Rumisha, S.F. \& Sindato, C., 2014 'The changing landscape of public health in sub-Saharan Africa: Control and prevention of communicable diseases needs rethinking', Onderstepoort Journal of Veterinary Research 81(2) Art. \#734, 6 pages. http://dx.doi.org/10.4102/ojvr. of Veterinary
$\mathrm{v} 81 \mathrm{i} 2.734$

McMichael, A. \& Woodruff, R., 2004, 'Climate change and risk to health', British Medical Journal 29(7480), 1416-1417. http://dx.doi.org/10.1136/bmj.329.7480.1416

Mwabukusi, M., Karimuribo, E.D., Rweyemamu, M.M. \& Beda, E., 2014, 'Mobile technologies for disease surveillance in humans and animals', Onderstepoor Journal of Veterinary Research 81(2), Art. \#737, 5 pages. http://doi:10.4102/ojvr. v81i 2.737

Ndiyoi, M., Rweyemamu, M. \& Meadows, K., 2006, 'Strengthening livelihoods through food and nutrition security in vulnerable SADC countries', mid-term review of OSRO/RAF/510-511/SAF, FAO, Rome, viewed 03 April 2014, from http://typo3. fao.org/fileadmin/user_upload/oed/docs/OSRORAF510_511SAF_2006_ER.pdf

Rushton, J., Häsler, B., De Haan, N. \& Rushton, R., 2012. 'Economic benefits or drivers of a 'One Health' approach: Why should anyone invest?', Onderstepoort Journal of Veterinary Research 79(2), Art. \#461, 5 pages. http://dx.doi.org/10.4102/ojvr. v79i2.461

Rweyemamu, M., Otim-Nape, W. \& Serwadda, D., 2006, Foresight. Infectious diseases: Preparing for the future: Africa, Office of Science and Innovation, London, $\mathrm{p}$. 1-120, viewed 03 April 2014, from http://www.bis.gov.uk/assets/bispartners/ foresight/docs/infectious-diseases/a1_id_africa.pdf

Rweyemamu, M.M., Paweska, J., Kambarage, D. \& Namuba, F, 2012, 'Towards one Africa, One Health: The SACIDS One Health focus on infectious diseases', Onderstepoort Journal of Veterinary Research 79(2), Art. \#449, 2 pages. http://dx.doi.org/10.4102/ ojvr.v79i2.449

Rweyemamu, M., Kambarage, D., Karimuribo, E., Wambura, P., Matee, M., Kayembe, J.M. et al., 2013, 'Development of a One Health national capacity in Africa: The Southern African Centre for Infectious Disease Surveillance (SACIDS) One Health virtual centre model', Currents Topics in Microbiology and Immunology 366, 7391. http://dx.doi.org/10.1007/82_2012_244

Southern African Centre for Infectious Diseases and Surveillance, n.d., Vision and mission, viewed 03 April 2014, from http://www.sacids.org/oweb/sacids/home/ about us/19-35/Vision__Mission.html

Taylor, L.H., Latham, S.M. \& Woolhouse, M.E., 2001, 'Risk factors for human disease emergence', Philosophical Transactions of the Royal Society of London. Series B: Biological Sciences 356(1411), 983-989. http://dx.doi.org/10.1098/ rstb.2001.0888

Waage, J., Banerji, R., Campbell, O., Chirwa, C., Collender, G., Dieltiens, V. et al., 2010, 'The Millennium Development Goals: A cross-sectoral analysis and principles for goal setting after 2015', The Lancet 376, 991-1023. http://dx.doi.org/10.1016/ S0140-6736(10)61196-8

World Bank, 2012, 'People, pathogens and our planet: The economics of one health', World Bank, Washington, DC, viewed 09 December 2013, from http://documents. worldbank.org/curated/en/2012/06/16360943/people-pathogens-planeteconomics-one-health

World Health Organization, 2011, Facts about health in the African sub-region Factsheet No. 314 WHO, Geneva.

Zinsstag, J., Schelling, E., Waltner-Toews, D. \& Tanner, M., 2011, 'From "one medicine" to "one health" and systemic approaches to health and well-being', Preventive Veterinary Medicine 101(3-4), 148-156. http://dx.doi.org/10.1016/j.
prevetmed.2010.07.003 